\title{
A munkajogi perek átalakulása
}

\author{
The Transformation of Labour Law Litigation
}

\begin{abstract}
ABSZTRAKT
Az elméleti és gyakorlati szakembereket a munkaügyi perek kialakulásától kezdve foglalkoztatja a kérdés, hogy az ezen alapvetően magánjogi többletelemekkel rendelkező jogterület milyen sajátos szabályozást igényel annak érdekében, hogy valamennyi résztvevő tisztességes eljárásban és bánásmódban részesülhessen. A tanulmány célja bemutatni, hogy a munkaügyi perek napjainkban miként alakulnak, vázolva az új kódexek hatálybalépésével előálló jelenségeket.
\end{abstract}

Kulcsszavak: munkaügyi per, polgári perrendtartás, munka törvénykönyve

\begin{abstract}
From the outset of labor litigation, both theoreticians and practitioners have been preoccupied with the question of what specific regulation this area of law - which has essentially additional elements of private law - requires in order to ensure fair treatment and proceedings for all participants. The aim of the present study is to show how labor litigation is evolving today, outlining the phenomena that have arisen due to the new labor and civil procedure codes.
\end{abstract}

Keywords: labour litigation, civil procedure code, labour code

Határozott meggyőződésünk szerint egy ideális jogrendszer akkor tud kielégítően müködni, ha annak az egyes részterületei közötti koherencia megtartott, valamint ha a különböző jogágakat szabályozó anyagi és eljárásjogi kódexek a felvetődő problémákra képesek adekvát és gyors választ adni, elkerülve a túlszabályozást. ${ }^{1}$ E körben tehát - az elméleti alapú kutatások eredményein túl - a joggyakorlat viszszajelzéseiből ${ }^{2}$ következtethet a jogalkotó arra, hogy a hatályban lévő jogszabályok

* Dr. Nádas György, egyetemi docens, Debreceni Egyetem Állam- és Jogtudományi Kar, Környezetjogi és Munkajogi Tanszék, e-mail: nadas.gyorgy@law.unideb.hu; Dr. Kiss Gergely Árpád, PhD-hallgató, Debreceni Egyetem Marton Géza Állam- és Jogtudományi Doktori Iskola, e-mail: kissgergelydsbk@gmail.com. A tanulmány az Igazságügyi Minisztérium jogászképzés színvonalának emelését célzó programjai keretében valósult meg.

${ }^{1}$ E jelenséget hívja Sárközy minőségi jogalkotásnak, hangsúlyozva ennek jelentőségét a különböző gazdasági folyamatokban. A szerző e körben az optimális mértéket az óvatos jogalkotás és a szükségszerü múltra irányuló dereguláció kettősének észszerű alkalmazásában látja. Bővebben SÁRKözY Tamás: A jog szerepe a gazdaságban. Magyar Tudomány, 2011/5, 535-540.

2 E körben igen hangsúlyos szerepet kapnak a bíróságok szervezetéről és igazgatásáról szóló 2011. évi CLXI. törvény (Bszi.) 29. § (1) bekezdése alapján a bírósági joggyakorlatot elemző csoportok. E testületek feladata, hogy a Kúria elnöke által kijelölt vizsgálati tárgyköröket elemezzék, és következtetéseiket összefoglaló vélemények formájában közzétegyék. Az összefoglaló vélemények a Kúria honlapján elérhetők: https://kuriabirosag.hu/hu/joggyakorlat-elemzo-csoportok-osszefoglaloi (2021. 05. 30.). 
működése mennyiben kielégítő, illetve hogy igényel-e változtatást, és ha igen, akkor milyen természetüt. ${ }^{3}$

Minderre figyelemmel arra a következtetésre juthatunk, hogy ha egy meghatározó jogszabályt hatályon kívül helyeznek és a tárgykörben új jogszabály születik, az igen jelentős hatást gyakorol a jogrendszer egészére, hiszen az egyes jogszabályok nem elszigetelt módon fejtik ki hatásukat.

Jelen tanulmány tárgya - a fentiekböl következően - annak vizsgálata, hogy az új munkajogi kódexünk valamint az új polgári perrendtartásunk milyen hatást gyakorolt a munkajog normatív hátterére, valamint az igényérvényesítés gyakorlatára. A fenti gondolatsor alapján jelen dolgozatban nem pusztán a jogszabályváltozások hatásának meglétét kívánjuk megállapítani (hiszen a jogalkotói szándék eleve az eltérő hatásgyakorlásra ${ }^{4}$ irányul), sokkal inkább annak vizsgálata a célunk, hogy az új anyagi és eljárásjogi törvénykönyv mennyiben gyakorolt hatást az egyes, a munkajogi jogviták keretein belül igen gyakran elöforduló perekre, különös figyelmet fordítva az igényérvényesítési hajlandóságra, valamint az egyes perek eljárási időtartamaira.

Ezek mellett szükségesnek tartjuk felhívni a figyelmet arra, hogy bár valamennyi peres eljárás meghatározó jelentőséggel bír a felek számára jogvitájuk eldöntésének mikéntje szempontjából, ugyanakkor a munkaügyi perek kapcsán e jelentőség a felek közötti hierarchikus viszonyra tekintettel hangsúlyosabban van jelen. Erre figyelemmel a munkajogi igényérvényesítés során a jogalkotási folyamatoknál még a szokásosnál is nagyobb körültekintéssel szükséges eljárni annak érdekében, hogy az alá-fölé rendeltségi viszonyok ellenére a peres eljárásokban az anyagi és az eljárási jogszabályok minden lehetőséget megadjanak a "gyengébb fél” számára is. ${ }^{5}$

${ }^{3}$ Az Igazságügyi Minisztérium számos helyettes államtitkára is segíti e folyamat gördülékenységét. $E$ tevékenység részleteiről az Igazságügyi Minisztérium Szervezeti és Müködési Szabályzatáról szóló 9/2019. (VIII. 1.) IM utasítás rendelkezik.

${ }^{4}$ Az Mt. esetében az új törvénykönyv megalkotására vonatkozó jogalkotói igény megfogalmazására a Széll Kálmán Terv keretein belül megalkotott Magyar Munka Tervben került sor. E dokumentum vizsgálja a foglalkoztatáspolitika, valamint a munkaerőpiac 2011-ben aktuális helyzetét, megfogalmazza az elérendő célokat, valamint az e célok eléréséhez szükséges intézkedéseket. A Magyar Munka Terv elérhető: https://2010-2014. kormany.hu/download/e/a7/40000/Magyar_Munka_Terv.pdf (2021. 05. 30.).

Az új Pp. vonatkozásában a polgári perjogi kodifikációról szóló 1267/2013. (V. 17.) Korm. határozat preambulumában a régi Pp. átfogó korszerüsítésére irányuló munkálatairól rendelkezik. Ez az új Pp. általános indokolásában is megjelenik: „A Koncepció az új polgári perrendtartásról szóló törvényjavaslat (...) főbb szabályozási céljaiként határozta meg a perhatékonyság rendszerszintü megvalósítását, a perelterelést, a felek közötti egyeztetést előmozdító eljárási szabályok kiépitését, az osztott perszerkezet bevezetését, a perkoncentrációt biztosító eljárási szabályok megteremtését, a törvényszéken induló perekben a professzionális pervitel garanciájaként a kötelező jogi képviselet előirását, a csoportper hazai szabályainak megalkotását és az ésszerü elektronizáció szerepének erősitését.” (Az új Pp. általános indokolása, I. Az új szabályozás szükségszerüsége) https://www.parlament.hu/irom40/11900/11900.pdf (2021. 05. 30.).

${ }^{5}$ E körülmény jelentőségét erősíti az is, hogy az új munkajogi kódexet kétségtelenül a rugalmasabbá válás és a megállapodás-központúság jellemzi. Ebből az is következik, hogy a munkavállalók védelme igen komoly veszélybe kerülhet, hiszen míg az alapvető elgondolása az új Mt.-nek, hogy a rugalmasság révén eljuthassunk a nagyarányú munkahelyteremtéshez, addig kontraproduktív eredmények születhetnek a jelenlegi munkaviszonyokkal kapcsolatban, ha a szabályozás nem elég alapos, vagy hibás alaptételeket állít fel. GYULAVÁRI Tamás-KÁRTYÁs Gábor: Effects of the New Hungarian Labour Code: The Most Flexible Labour Market in the World? Friedrich Ebert Stiftung Budapest Office (www.fesbp.hu), 233-245. http://real.mtak. hu/81493/1/166_711_1_PB_u.pdf (2021. 05. 30.). 


\section{A munkaügyi jogviták önállósodásának kezdetei}

A munkaügyi per - pontosabban a munkaügyi bíráskodás - a 13. századra visszavezethető gyökerekkel rendelkezik, ugyanis már az 1200-as években megjelentek az úgynevezett céhbíróságok, amelyek elsősorban az akkori céhes iparszervezési szerkezetben tevékenykedők jogvitáit voltak hivatottak elbírálni. ${ }^{6} \mathrm{~A}$ kezdetleges intézményesülést követően a modern munkaügyi bíráskodásról az 1800-as évek kezdetétöl beszélhetünk, ugyanis a napóleoni Franciaországban, Lyonban létesült 1806-ban Európában az első, főként a selyemiparban foglalkoztatott dolgozók és munkáltatóik között jogviták feloldását célzó munkaügyi bíróság. ${ }^{7}$ Hosszas formálódás és fejlődés következtében megvalósult ezen ügytípusok különálló kezelése, bár az európai államok között nem volt teljes egység arra nézve, hogy miként alakítsák a munkajogi jogvitákkal kapcsolatos ítélkezési struktúrát. $E$ körben érdemes idézni Prugberger Tamás megállapításait, aki négy különböző csoportra (modellre) osztotta a munkaügyi bíráskodást, megkülönböztetve a francia, az olasz, a holland és az angolszász modelleket. ${ }^{8}$ A differenciálás szempontjait a jogviták természete, az eljáró bíróságok hatásköri kérdései, valamint az ítélkező szervezetek összetétele adta.

A magyarországi munkaügyi bíráskodás a kiegyezést követő ipari és tudományos fellendülés következtében formálódott: Konkrét elözményeként az ipartörvényröl szóló 1872. évi VIII. törvénycikk jelölhető meg. ${ }^{9}$ Kiemelendők az 1884. évi XVII. törvénynek a munkaügyi bíráskodás megszilárdításáról szóló rendelkezései (bár a polgári perrendtartásról szóló 1911. évi I. törvénycikk rendelkezései e jogvitákat járásbírósági hatáskörbe utalták). ${ }^{10}$

Amint az a fentiekböl is látszik, a munkajogi jogviták elbírálásával kapcsolatos „különleges bánásmód” igénye nem új keletü eljárásjogi újitás napjainkban, hanem egy jelentős múltra visszatekintő, jogalkotási szükségszerüségként mutatkozó kulturális bázis.

${ }^{6}$ RomÁN László: Munkajog. Tankönyvkiadó, Budapest, 1989; Horváth Attila (szerk.): Magyar állam- és jogtörténet. Nemzeti Közszolgálati Egyetem Közigazgatás-tudományi Kar, Budapest, 2014, 128.

${ }^{7}$ KuLISITY Mária: A munkajogi biráskodás aktuális kérdése és problémái. OTDK-dolgozat, kézirat, Budapest, 2001, 233-234. https://edit.elte.hu/xmlui/handle/10831/34782 (2021. 05. 10.).

${ }^{8}$ Prugberger Tamás: Magyar és Európai munkajog. Közgazdasági és Jogi Könyvkiadó, Budapest, 1999, 327-339.

${ }^{9} \mathrm{E}$ jogszabály 76 . §-a az alábbiakat rögzítette: „Ugyanazon vagy különböző ipart egy vagy több községben önállóan gyakorló iparosok közös érdekeik elömozditása végett ipartársulatokká egyesülhetnek. Ezen ipartársulatoknak jogában áll az iparosok és segédszemélyzetük közt keletkező surlódásokat és peres kérdéseket a külön e czélból felállitandó békéltető bizottság utján, melybe egyenlő számmal segédek is felveendők, kiegyenliteni." Fontos említeni, hogy az ipartársulatok - és békéltető bizottságaik - még nem tekinthetök általános hatáskörü ítélkező szerveknek, figyelemmel arra, hogy az ipartársulati tagság (a jogszabály 79 . §-a alapján) föszabály szerint sem kikényszeríthető, sem megtagadható nem volt.

10 1. § A járásbiróság hatáskörébe tartoznak: (...) 2. tekintet nélkül a per tárgyának értékére: (...) e) a szolgálati szerződésből a munkaadó és a munkavállaló közt felmerülö perek (...) 


\section{A munkaügyi jogviták napjainkban}

A munkaügyi perekkel kapcsolatos szabályozás a polgári perrendtartásról szóló 2016. évi CXXX. törvényben (Pp.) külön fejezetet kapott. ${ }^{11} A$ szabályozás lényege a lex specialis derogat legi generali elv alapján az, hogy ezekre a perekre is a Pp. szabályait kell alkalmazni, kivéve, ha a Pp. e fejezete eltérő rendelkezést tartalmaz. A munkaügyi perek fogalmának tisztázásához a Pp. egy taxatív felsorolást ${ }^{12} \mathrm{ad}$. A pertípus fogalmának (kategóriájának) tisztázásán túl tartalmaz olyan rendelkezéseket, amelyek valamelyest ellensúlyozni kívánják a munkavállalók egyébként előnytelenebb helyzetét mind infrastrukturális, mind financiális tekintetben. $E$ körben a munkavállalói oldalon megjelenő könnyebbségekről beszélhetünk a tárgyalást lefolytató bíróságok illetékessége tekintetében, az egyes soronkívüliségre vonatkozó szabályokkal, a bizonyitási teher egyes kérdésekben jogszabályi rögzítésével, valamint a költségekkel kapcsolatosan. Álláspontunk szerint a költségeket illető kedvezmények bírnak az egyik legjelentősebb hatással e körben, figyelemmel arra, hogy - bizonyos feltételek teljesülése esetén ${ }^{13}$ - a perköltség mértéke nem hat riasztóan

${ }^{11}$ Pp. XXXIX. fejezet, 508-525. §.
${ }_{12}$ 508. § [A munkaügyi per]

(1) Munkaügyi peren e fejezet alkalmazásában

a) a munka törvénykönyvéről szóló 2012. évi I. törvény (a továbbiakban: Mt.) alapján létesített,

b) a közalkalmazotti,

c) - törvényben foglalt kivételekkel - a szolgálati,

d) a közfoglalkoztatási,

e) a sporttörvény alapján kötött munkaszerződéses,

f) a szakképzés során kötött szakképzési munkaszerződésböl eredö,

g) a nemzeti felsőoktatási törvény szerinti hallgatói munkaszerződésből eredő,

h) a szociális szövetkezettel és foglalkoztatási szövetkezettel létesített tagi munkavégzési jogviszonyból (a továbbiakban együtt: munkaviszony) származó pert kell érteni.

(2) Az (1) bekezdésben foglaltakon túl e fejezet alkalmazásában munkaügyi per az Mt. 285. § (1) bekezdése szerinti további munkajogi igény érvényesitésével kapcsolatos per.

${ }^{13}$ E körben a Pp. 525. § (1)-(3) bekezdései a következőket rögzíti: „Ha a munkaügyi per által érintett munkaviszonyból származó távolléti dij nem haladja meg a jogszabályban meghatározott mértéket, a perben félként részt vevő munkavállaló munkavállalói költségkedvezményre jogosult. A felet a munkavállalói költségkedvezmény alapján - jogszabály eltérő rendelkezése hiányában - a keresetlevél előterjesztésétől kezdve, a per egész tartamára, valamint a végrehajtási eljárásra is kiterjedően költségmentesség illeti meg. A munkavállalói költségkedvezményre vonatkozó adatokat a keresetlevélben fel kell tüntetni, illetve ahhoz csatolni kell a szükséges iratokat. A fél jogosultságát a bíróság a csatolt iratok alapján hivatalból vizsgálja. A fellebbezés, illetve a felülvizsgálat ügyében eljáró bíróság - a fellebbezés, illetve a felülvizsgálati kérelem korlátaira tekintet nélkül - hivatalból vizsgálja a munkavállalói költségkedvezményre jogosultság feltételeinek fennállását." E körben szükséges még említést tenni a munkavállalói költségkedvezmény megállapításáról és érvényesítésének szabályairól szóló 73/2009. (XII. 22.) IRM rendeletről, ugyanis a ,jogszabályban meghatározott mértéket” e jogszabály 1. §-a rögzíti a munkaviszonyból származó távolléti díj vonatkozásában: „A munkaügyi perben félként résztvevő munkavállaló (a továbbiakban: munkavállaló) munkavállalói költségkedvezményre abban az esetben jogosult, ha a per által érintett munkaviszonyból származó bruttó havi átlagkeresete a) a keresetlevél benyújtásakor, b) ha a munkaviszony korábban megszünt, annak megszünésekor, vagy c) ha a munkaügyi per a munkaviszony jogellenes megszüntetése tárgyában indult, a munkáltató munkaviszony megszüntetésére irányuló jognyilatkozata közlésének időpontjában nem haladja meg - a Központi Statisztikai Hivatal által közzétett - az a)-c) pontok szerinti időpontot megelőző második év nemzetgazdasági bruttó havi átlagkeresetének kétszeresét." 
a munkavállalókra, ezáltal jogosnak vélt igényük érvényesítésében aktívabban fel tudnak lépni.

A jogszabályi háttér rövid áttekintését követően érdemesnek találjuk vizsgálat tárgyává tenni a munkajogi igényérvényesítés egyes gyakorlati kérdéseit. Ahhoz azonban, hogy a folyamatok mélyebb összefüggéseit meg lehessen érteni, elengedhetetlen megvizsgálni a jogszabályi háttérnek a közelmúltban lezajlott, a munka világára markáns hatást gyakorló megváltozását, egyaránt koncentrálva az anyagi és az eljárásjogi kérdésekre.

Az új Mt. a hatálybalépésével14 igencsak „megkavarta az állóvizet”, ugyanis számos koncepciózus változtatás látott napvilágot, amelyek a munkaügyi perek természetét alapjaiban képesek átalakítani. ${ }^{15}$ Egy új szabályozás megalkotása magában hordozhatja a jelenlegi jogi környezet rosszabbá válásának kockázatát, de ennek veszélye nem olthatja ki a megújulás iránti igényt. Egyetértünk Kun Attila gondolataival az új munkajogi kódex kapcsán: egy ilyen volumenü jogszabály megalkotása elengedhetetlenné teszi a munka világának holisztikus megközelítését, ideértve különösen a szakpolitikai és tudományos álláspontokat, a jogtudomány segédtudományai által feltárt társadalmi háttér-információkból eredő releváns információkat és adatokat, valamint a nemzetközi tapasztalatokból fakadó, vagy azokból közvetetten eredő „jó gyakorlatokat”. E gondolatok szerzőjének álláspontja jó eséllyel nevezhető pesszimizmussal áthatott reménykedő prognózisnak, ugyanis: „Jogtechnikai értelemben tehát »él, « jól funkciónál a törvény. Jogpolitikai, jogszociológiai és társadalmi szempontból azonban a kódex hatásának megitélése aggályos lehet. Egyfelöl, a kitüzött nagyívü célok teljesülése alig történt/történik/történhetett meg, illetve nem kalkulálható, másfelöl viszont egyéb - közöttük károsnak tekinthetö - hatások jelentkezése kimutatható. ${ }^{116}$ Ha röviden össze akarnánk foglalni e gondolatokat, akkor talán azt mondhatjuk, hogy a jelenlegi szabályozás pragmatikus megközelítéssel nézve beváltotta a hozzá füzött szakmai és piaci igényeket, azonban számos olyan potenciális veszélyt hordoz magában, amelyeket elsősorban a gyakorlati alkalmazás fog majd kidomborítani.

A jelenleg hatályos szabályozás alapvetően írta át az egyes jogintézményekhez kapcsolódó, illetve az azok megsértéséből eredő igényeket. Az már korábban is jól látható volt, hogy a munkajogi konfliktusok körében igen magas a látencia. A munkavállalók igényérvényesítési, illetve érdekérvényesítési hajlandósága és képessége az anyagi jogi jogszabályok változását követően az alább ismertetett statisztikai adatokkal is alátámasztható módon jelentős mértékben csökkent.

\footnotetext{
${ }^{14}$ Az új Mt. 2012. július 1. napjával lépett hatályba, ugyanakkor a kódex bizonyos rendelkezései 2013. január 1. napjától váltak alkalmazhatóvá.

${ }^{15}$ A teljesség igénye nélkül Kun Attila: Az új munka törvénykönyve. Az MTA-PTE Összehasonlító és Európai Foglalkoztatáspolitikai és Munkajogi Kutatócsoport keretei között készült tanulmány, kézirat, 2016, 385-412. https://jog.tk.hu/uploads/files/13_Kun_Attila.pdf; GYULAVÁRI Tamás: Út a rugalmasságba. In: Kun Attila (szerk.): Az új munka törvénykönyve dilemmái címü tudományos konferencia utókiadványa. KRE ÁJK, Budapest, 2013, 91-104.; LEHOCZKYNÉ KOLLONAY Csilla: Génmanipulált újszülött - Új munkatörvény az autoriter és neoliberális munkajogi rendszerek határán. In: Az új munka törvénykönyve dilemmái címü tudományos konferencia utókiadványa. KRE ÁJK, Budapest, 2013, 24-56.; BERKE Gyula-Kıss György-LőRINCz GyörgyPÁL Lajos-PETHÖ Róbert-HORVÁTH István: Tézisek az új Munka Törvénykönyve szabályozási koncepciójához. Pécsi Munkajogi Közlemények, 2009/3, 147-160.

${ }^{16}$ KUn (2016): i. m., 385.
} 
Ennek hátterében (ma már kijelenthetjük), egyértelmüen a munkajogi szabályok megváltozása áll. Ezek közül az alapvető változások közül két elemet mindenképpen szükséges kiemelnünk. Az egyik, amely a korábbi Mt. hatálya alatt indult munkaügyi peres eljárások döntő többségét képezte, a felmondás jogellenességének megállapítása és az ehhez füződő jogkövetkezmények iránti eljárások. A korábbi anyagi jogi szabályok kielégítették azt az igényt, hogy amennyiben a munkáltató nem a jogszabályokban meghatározottak szerint szüntette meg a munkaviszonyt, úgy olyan szankcióval kelljen számolnia, amely már önmagában a kilátásba helyezéssel is alkalmas eszköz arra, hogy a munkáltatót a jogellenes magatartás tanúsításától visszatartsa.

A jelenlegi szabályozás viszont ezt az elvárást egyáltalán nem elégíti ki, ebböl következően a munkavállalók jelentős része nem vállalja annak a kockázatát, hogy igényét peres eljárásban érvényesítse. A jelenlegi anyagi rendelkezések figyelembevételével a munkáltatónak még akkor is „megérheti” a munkavállaló munkaviszonyát megszüntetni, ha jognyilatkozata nem felel meg a jogszabályi rendelkezéseknek. Ekkor akár vállalja a per kockázatát, amelynek a végén legfeljebb - teljes pervesztesség esetén is -12 havi távolléti dijnak megfelelö összeget kell fizetnie. Abban az esetben, ha a munkavállalónak sikerül elhelyezkednie, netán magasabb bérért, mint a korábbi munkáltatójánál elért, kára nem keletkezik, így legfeljebb az Mt. 82. § (4) bekezdésében rögzítetteket követelheti. ${ }^{17}$ Ez pedig a perindítási hajlandóságra semmiképpen sem gyakorol ösztönző hatást. E megállapításunkat alátámasztják a Debreceni és a Nyíregyházi Törvényszék által szolgáltatott peradatok. ${ }^{18}$

Ugyancsak a peres eljárások számának visszaeséséhez vezetett, hogy a követelhető összeg jogcíme is megváltozott: elmaradt munkabér helyett kizárólag elmaradt jövedelem címén járó kártérítést kérhet a sérelmet szenvedett munkavállaló. E körben nagyon élesen vetődik fel az a dogmatikai probléma, amelyet az Mt. 29. § (5) bekezdése rögzít. ${ }^{19}$ Ugyanis azzal kell szembesülnünk, hogy dogmatikai szempontból a jogellenes felmondás semmis, de a jogalkotó kizárja a semmisség jogkövetkezményeinek alkalmazását. A jogcím megváltozása azzal a következménnyel jár, hogy a munkavállaló a munkaviszony jogellenes megszüntetését követően, amennyiben nem tudott, illetve nem tud elhelyezkedni, már nem lesz biztosított, hiszen a bíróság

${ }^{17} \mathrm{Az}$ Mt. 82. § (4) bekezdés szerint a munkavállaló követelheti a munkáltatói felmondás esetén irányadó felmondási időre járó távolléti díjnak megfelelő összeget.

${ }^{18}$ A Nyíregyházi Törvényszék 1998. évben a munkaviszony megszüntetése kapcsán 55 ügyet bírált el másodfokon, ez 2000-ben 63 volt. 2009-ben 51, míg 2014-ben már csak 45, 2015-ben 32, 2016-ban 23, 2017-ben 31, 2018-ban 25, 2019-ben 8. Ezek az adatok jól mutatják azt, hogy a munkavállalók perhajlandósága a szabályok megváltozása, illetve a pernyertesség esetén a munkáltatót terhelő fizetési kötelezettség jelentős korlátozása miatt lecsökkent. Nem éri meg nekik a többéves peres eljárás, amely egyébként jelentős költségvonzattal is jár. Kétségtelen tény, hogy a munkaügyi perek száma összességében is csökkenést mutat, amelynek hátterében a tanulmány egyéb részeiben felvázolt perjogi változások, illetve a peres eljárás során felmerülö költségek növekedése is szerepet játszik. Ezt az állítást is alátámaszthatja a Nyíregyházi Törvényszék által megküldött adatsor, amely szerint például az összes munkaügyi peres fellebbezett ügy 2004-ben 196, míg 2014-ben 103 volt. Ezzel szemben 2017-ben ismét 139 fellebbezett ügyben járt el a Nyíregyházi Törvényszék, de ebből munkaviszony megszüntetésével összefüggő ügy csak 31 volt.

${ }^{19}$ Az Mt. 29. § (5) bekezdése szerint a munkaviszony megszüntetésére irányuló jognyilatkozat érvénytelensége esetén - a munkáltató saját jognyilatkozatának sikeres megtámadását kivéve - a 82-84. §-ban foglalt rendelkezéseket kell megfelelően alkalmazni. 
által megítélhető kompenzáció már nem elmaradt munkabérként, hanem ahogy fentebb írtuk, kártérítésként állapítható meg. Ezt a vélekedést látszik alátámasztani az Mt. 171. § (2) bekezdése is. ${ }^{20}$ Ezzel összefüggésben a Kúria 3/2014. (III. 31.) KMK véleménye többek között rámutat arra, hogy megfelelöen alkalmazni kell az Mt.-nek a munkáltató kártérítési felelősségére vonatkozó XIII. fejezetét.

Ugyancsak az eljárásokat érintő, de az anyagi jogszabályban meghatározott követelmény az, hogy a peres eljárást - a korábbi szabályokkal egyezően - a jogellenesnek ítélt jognyilatkozat közlésétöl számított 30 napon belül elö kell terjeszteni. A korábbi Mt. azért tartotta szükségesnek a perindítási határidőt az általános elévüléshez képest ilyen mértékben lerövidíteni, mert a jogellenesség jogkövetkezménye elsősorban az eredeti munkakörben történő továbbfoglalkoztatás (visszahelyezés) volt, illetőleg a perindítással egy függő helyzet jött létre, amelynek fenntartása jogbizonytalanságot eredményezett. Ma már azonban ez a rövid perindítási határidő nem indokolható, hiszen a kereset kapcsán kizárólag anyagi igényekröl dönt a törvényszék, illetve, ahogy arra fentebb utaltunk, továbbfoglalkoztatásra, pontosabban ilyen irányú kereset előterjesztésére csak nagyon szűk körben nyílik lehetőség. Azzal azonban, hogy ilyen esetben a munkavállaló mellett a munkáltató sem kérheti a továbbfoglalkoztatás mellőzését, az átalány kártérítés lehetősége kizárt maradt továbbra is.

A másik jelentős munkaügyi pertípus a kártérítési perek köre. A kártérítés anyagi jogi szabályait szintén újradefiniálta a jogalkotó, a munkáltatói kárfelelősség szabályai vonatkozásában pedig az anyagi jogi értelemben vett bizonyítási teher, a kimentés lehetőségét biztosító tényállások tartalma és értelmezése alakult át. Mindez számos ponton bizonytalanná teszi a per kimenetelét a felek számára. A polgári jogias szemlélet nagyon sajátos módon jelenik meg a munkavállaló kártérítési felelőssége kapcsán, ahol is a munkavállaló felelősségének alapja a felróhatóság, de a kártérítés mértékét kifejezetten vétkességi alapokra helyezi a jogalkotó. ${ }^{21}$

A munkaügyi jogviták számának csökkenéséhez vezethetett az a körülmény is, hogy a korábban a munkavállaló oldaláról egyértelmüen költség- és illetékmentes perek klasszikus értelemben megszüntek. A jogalkotó a munkavállalói költségkedvezmény intézményének kialakításával ma már a vitássá tett jogviszonyból származó jövedelem nagyságához köti a költségmentességet. A szabály a költségfeljegyzési jog intézményét nem érinti, tehát a munkavállaló a költségek elölegzése nélkül indíthat pert, azonban ha a jövedelme a miniszteri rendeletben meghatározott mértéket meghaladja, úgy esetleges pervesztesség esetén köteles megfizetni az eljárási illetéket és az egyéb költségeket. A szabályozás kritikáját abban fogalmazhatjuk meg, hogy a költségmentességet a munkaviszony fennállása alatt megszerzett jövedelem nagyságához igazítja a jogszabály, de nem veszi figyelembe, hogy ha a jövedelem-

${ }^{20} \mathrm{Az}$ Mt. 172. $\S(2)$ bekezdése szerint a kártérítés alapjául szolgáló jövedelem meghatározásánál a jövedelmet - a jogosultat a társadalombiztosítási szabályok szerint terhelö - járulékkal csökkentett összegben kell figyelembe venni.

${ }^{21}$ NÁDAS György: A munkáltató kártérítési felelősségének jogalapja, jellemzői, a felelősség alóli mentesülés esetei. In: Bukor József-Drahota-Szabó Erzsébet-Simon Szabolcs-Tóth Sándor János (szerk.): A Selye János Egyetem 2017-es „Érték, minőség és versenyképesség - a 21. század kihívásai” Nemzetközi Tudományos Konferenciájának tanulmánykötete. Humán tudományi szekciók. SJE, Komárno, 2017, 349. 
szerző jogviszony esetleges megszünését követően a munkavállaló jövedelmi viszonyai hátrányosan változhatnak meg, így a korábbi jövedelem alapján számított magas költségek utólagos megfizetése komoly anyagi nehézséget jelenthet az itélethozatal időpontjában (esetlegesen) megváltozott anyagi körülmények között.

Ugyancsak a költségek számbavétele és a perhajlam csökkenése körében szükséges rámutatni arra, hogy amennyiben jogi képviselőt kíván igénybe venni a munkavállaló, az is jelentős kiadást eredményez. Megjegyezzük, hogy a hatályos perjogi szabályok fényében a jogi képviselet viszont szinte elengedhetetlen.

A jogszabályváltozásnak ezen objektív körülmények mellett vannak szubjektív utóhatásai is. Ebbe a körbe kell sorolnunk az ítélkezési gyakorlat elbizonytalanodását, és az új jogintézményekkel kapcsolatosan azt is megállapíthatjuk, hogy kiforrott jogalkalmazói, ítélkezési gyakorlat nem minden esetben alakult még ki. Az egyes perek kimenetele különböző bíróságok és bírói tanácsok előtt különböző lehet. Ebben az is közrejátszhat, hogy a Kúria szervezetében nem alakítottak önálló munkaügyi kollégiumot, és a munkaügyi bíróságok helyzete is folyamatosan instabil volt, olyannyira, hogy mára az önálló munkaügyi bíráskodás meg is szűnt. ${ }^{22}$ Ennek a bizonytalanságnak a kockázatát a peres felek viselik, amelyet (a költségek viselésének már említett változásaival) sokszor olyan fokú kockázattá minősítenek, hogy a pert megelőző egyeztetéseken inkább megegyeznek, vagy a jogaiban sértett fél megegyezés hiányában is eltekint a keresetindítástól. Ezen a problémán az alternatív vitarendezési megoldások tudnának segíteni, hiszen azok időben és költségben is jelentősen kedvezőbbek lennének a felek számára - de e megoldások ez idáig jogszabályi felhatalmazás ellenére sem keltették fel a munkaviszony szereplőinek érdeklődését.

A munkaügyi pereket alapvetően érintette a polgári perrendtartásról szóló 2016. CXXX. törvény hatálybalépése. Az új perjogi koncepció lényege a professzionális perképviselet: a jogszabály a tökéletesen felkészült jogi képviselők és bíróság idealizált képét festi le. Ez az elméleti megoldás különösen munkaügyi perekben - ahol a költségek nagysága miatt a munkavállalók gyakran személyesen járnak el - nagyon nehezen kivitelezhető. Az osztott perszerkezet már önmagában is olyan bonyolulttá teszi a peres eljárást, hogy azt a laikus fél csak nagy nehézségek árán képes sikeresen végigvinni. A munkaügyi perek további sajátossága éppen az anyagi jogból, illetve a jogviszony magánjogi jegyeket is hordozó, de alapvetően alá-fölé rendeltségi struktúrájából következően, az, hogy a munkavállaló, amennyiben a perben eljárásjogi értelemben vett bizonyítás őt terheli, csak nagy nehézségek árán tud teljesíteni. Pedig minden jogkereső állampolgár érdeke, hogy a polgári igazságszolgáltatás kiszámítható - az eljárás menete jól átlátható, az egyes perbeli cselekmények kerete, időtartama egyértelmű - legyen, és igazodjon korunk megváltozott követelményeihez. ${ }^{23}$

\footnotetext{
22 RAB Henriett: A közszolgálati különbíráskodás HR-szempontú vizsgálata. Közjogi Szemle, 2016/3, 8-12.; JAKAB Nóra-PRUgBeRger Tamás-TóTH Hilda: A magyar munka- és a közszolgálati jogi szabályozás alakulása a rendszerváltás után. Polgári Szemle, 2020/1-3, 287-313.; PRugBERger Tamás-RÁcz Zoltán: A munka- és a közszolgálati jogi érdekérvényesítés alakulása 2010 után. Polgári Szemle, 2017/4-6, 184-201.

${ }^{23}$ CSÉFFÁN József: A munkaügyi perek elbírálására vonatkozó speciális perrendi szabályok. Munkajog, 2018/1, 54.
} 
Ha a laikus fél kíván perlekedni, már a keresetlevél előterjesztésénél olyan akadályokba ütközik, amelyek jelentős mértékben visszaszorítják a perlési hajlandóságot. Az igényérvényesítés kapcsán további nehézséget jelent, hogy a bíróság az ítéleti tényállás megállapításához szükséges körben igyekszik a peres feleket, köztük a laikus munkavállalót is meghallgatni, aki gyakran a szavak köznyelvi jelentését használja, figyelmen kívül hagyva az egyes nyilatkozatok esetleges jogi relevanciáját. A törvény emellett új alapokra helyezi, és rendszerében megújítja a polgári perek lefolytatásának szabályait. Az új szabályozás alábbi vezérlőelvei a munkaügyi perekben is irányadók: a) a felek szabadon rendelkezhetnek perbe vitt jogaikkal (rendelkezési elv); b) a bíróságnak és a feleknek törekedniük kell arra, hogy az ítélet meghozatalához szükséges valamennyi tény és bizonyíték olyan időpontban álljon rendelkezésre, hogy a jogvita lehetőleg egy tárgyaláson elbírálható legyen (perkoncentráció elve); c) a félnek a peranyagot a per mihamarabbi befejezését elösegítő módon, jóhiszemüen kell előadni, továbbá felelős a saját perviteléért, perbeli mulasztásaiért (eljárástámogatási, igazmondási kötelezettség, jóhiszemüség elve); d) a bíróság a perkoncentráció érvényesülése érdekében a törvényben meghatározott módon és eszközökkel hozzájárul ahhoz, hogy a felek eljárási kötelezettségeiket teljesíthessék (bíróság közrehatási tevékenységének elve). ${ }^{24}$

A munkajogi anyagi jogalap sokszor polgári jogi tényállásokhoz kötődik, így a tényállások és jogállítások ok-okozati összefüggésének feltárása a munkaügyi per egyik sajátos nehézsége ${ }^{25} \mathrm{~A}$ rendkívül összetett jogszabályi háttér sok esetben igényli a polgári jogi ítélkezési gyakorlat feltárását és az ott kialakított precedenseknek a munkajogba történő átültetését is. Arról nem is beszélve, hogy a különböző foglalkoztatási jogviszonyban maga az anyagi munkajogi szabály is különbözően rendelkezik.

Ezen a bonyolult perjogi szituáción bizonyos értelemben enyhít a perrendtartás, amikor az úgynevezett állítási, illetve bizonyítási szükséghelyzet jogintézményét megteremti, hiszen ezen keresztül a bizonyításra köteles fél a bizonyítás terhét legalább részben a másik, erősebb félre tudja hárítani. Különösen fontos és jelentős jogintézménye lehet ez a munkaügyi pereknek, hiszen a munkaügyi jogvitákban a legtöbb munkaviszonyt érintő adattal, bizonyítékkal a munkáltató rendelkezik, ezért életszerủ az az elvárás hogy a bizonyítás terhét nagyobb mértékben a munkáltató viselje. Az újabb bírói gyakorlat ${ }^{26}$ a kirívóan információ-aszimmetrikus helyzetekben már eddig is felmentést adott a "gyengébb" fél számára azoknak a konkrét tényeknek az állítása és bizonyítása alól, amelyek szükségesek lettek volna egyébként a perbeli igénye sikeres érvényesítéséhez, és az ezt kizáró tényállítások és bizonyítások terhét az ellenfélre telepítette. ${ }^{27}$

Ezzel együtt lényeges, hogy a perbeli bizonyítás szabályai alapvetően befolyásolják az eljárás kimenetelét, mivel a bizonyítatlanság következményeit mindig az vise-

${ }^{24}$ CSÉFFÁN: i. m., 58.

${ }^{25}$ NÁDAS György: Bizonyítási nehézségek a munkaügyi kártérítési perekben. Munkaügyi Szemle, 2002/5, 51.

${ }^{26}$ EBH 2009.1956., BDT 2010.2355., 2010.2319., 2008.1801., 2007.1689.

${ }^{27}$ Petrik Ferenc (szerk.): Polgári eljárásjog I-II. - Kommentár a gyakorlat számára. Elektronikus kiadvány. HVG-ORAC, Budapest, 2020. 
li, aki a bizonyítási érdeket hordozza. ${ }^{28} \mathrm{~A}$ bizonyítás különös nehézségét adja, hogy a bizonyítandó tények és körülmények igazolására olyan tanúkat kell kihallgatni, akik az egyik peres féllel alá-fölé rendeltségi viszonyban, míg a másikkal kollegiális viszonyban állnak. Így az elfogulatlanság erősen megkérdőjelezhető. E koordinátarendszerben a feleknek sokszor a bíróság bölcsességére, tapasztalatára és lényeglátására kell hagyatkozniuk.

A perjogi szabályok alkalmazását, illetve a per anyagi jogi értelemben vett eldöntését a munkaügyi jogvitákban gyakran akadályozza az az anyagi jogszabály, amely tételesen meghatározza, hogy mit tekinthetünk munkaviszonyra vonatkozó szabálynak. Ez alatt az Mt. 13. § szerint nemcsak a jogszabályokat, de a kollektív szerződést, az üzemi megállapodást, az egyeztető bizottság kötelező határozatát is érteni kell. Ez azt is jelenti, hogy a peres feleknek, illetve a jogvitában eljáró bíróságnak nemcsak az anyagi jogi jogszabályokat, de a fentebb említett jognyilatkozatokat is vizsgálódási körünkbe kell vonni és értelmezni, adott esetben az értelmezést segítendő külön bizonyítást felajánlani, illetve az eljáró bíróságnak lefolytatni.

Álláspontunk szerint ezek a jogszabályi változások mind abba az irányba hatnak, hogy a munkaügyi jogvitákat a felek ne a peres eljárás keretei között oldják meg. Ez egyrészt azt jelenti, hogy az érintett felek igényeiket - még ha azok jogosak lennének is - nem érvényesítik, vagy alternatív vitarendezési megoldást keresnek. (Megjegyzendö, hogy ez utóbbi ma csekély mértékben van jelen.)

Külön vizsgálat szükséges a kollektív munkajog alanyai közötti jogvitáknál. Ezek száma a korábbi eljárásrend mellett sem volt magas, mára pedig azt mondhatjuk, hogy a kollektív munkaügyi jogviták elenyésző számban jelennek meg a munkaügyi pereket tárgyaló bíróságok előtt.

$\mathrm{A} z$, hogy ennek milyen okai vannak, részben meghaladja jelen tanulmány kereteit, részben pedig magán a jogtudományi vizsgálódás keretein is túlmutatnak, ezért elsősorban azokat a jogi csomópontokat vizsgáljuk, amelyek a kollektív munkaügyi jogviták láthatatlanságához vezettek.

A Pp. egyik jelentős és előremutató szabálya az 514. § (1) bekezdése, amely szerint a perben fél lehet az a szakszervezet, munkáltatói érdekképviseleti szervezet vagy üzemi, közalkalmazotti tanács is, amelynek egyébként nincs perbeli jogképessége. Az üzemi tanács, illetve a közalkalmazotti tanács is peres féllé válhat tehát annak ellenére, hogy ez a két intézmény sem általános jogképességgel, sem különös perbeli cselekvőképességgel nem rendelkezik. Ennek az eljárásjogi szabálynak anyagi jogi értelemben vett következményei is lehetnek, tudniillik az üzemi tanács meghatározott feltételek esetén úgynevezett normatív hatályú üzemi megállapodás kötésére is jogosult, annak ellenére, hogy anyagi jogi értelemben és a polgári jog általános szabályai szerint szerződéskötési képességgel egyáltalán nem rendelkezik. ${ }^{29}$

A szakszervezetek jogalanyisága és ebböl következően perbeli cselekvőképessége már a korábbi szabályozás alapján is tisztázott volt. Ez tehát a kollektív mun-

\footnotetext{
${ }^{28}$ KóRóDI Balázs: Perbeli szükséghelyzetek az egészségügyi szolgáltatással összefüggésben keletkezett hátrányok miatti perekben. Magyar Jog, 2020/1, 13-19.

${ }^{29}$ Lásd erröl részletesen BAGDI Katalin: A participációs jogok szerepe a munkaviszonyban. Doktori értekezés, kézirat, Debrecen, 2020.
} 
kaügyi jogvitákat, illetve azok számát érdemben nem befolyásolja. Ezzel szemben az üzemi tanácsok perképességének elismerése egyértelművé teszi, hogy az üzemi tanács önálló szereplője a munkajognak - azzal a kitétellel, hogy anyagi jogi értelemben vett önállósága a jelenlegi jogszabályi környezetböl nem vezethető le. A Pp. hatálybalépése óta ez a változás azonban a statisztikák adatai szerint a perek számának érdemi emelkedését nem hozta.

\section{Peradatok}

A következő részben a jelen vizsgálat alapját két keresztmetszeten keresztül kívánjuk bemutatni, nevezetesen az ügyek számát és az eljárási időket illetően, amely adatokból levonhatjuk következtetéseinket.

\section{1. Ügyek alakulása I.: ügyszám}

Folytatva a korábbi gondolatmenetet, a következőkben érdemesnek tartjuk azt megvizsgálni, hogy az új Mt. hatálybalépése mennyiben érintette a perindítási hajlandóságot. E körben az Országos Bírósági Hivatal $(\mathrm{OBH})$ által közzétett nyilvános adatokat $^{30}$ vettük alapul.

1. táblázat. Ügyek száma (2015-2020)

\begin{tabular}{|l|c|c|c|}
\hline \multicolumn{1}{|c|}{ Év } & $\begin{array}{c}\text { Érkezett ügyek } \\
\text { száma }\end{array}$ & $\begin{array}{c}\text { Befejezett ügyek } \\
\text { száma }\end{array}$ & $\begin{array}{c}\text { Folyamatban maradt } \\
\text { ügyek száma }\end{array}$ \\
\hline $\mathbf{2 0 1 5}$ & 14273 & 14670 & 7060 \\
\hline $\mathbf{2 0 1 6}$ & 13477 & 14307 & 6230 \\
\hline $\mathbf{2 0 1 7}$ & 12667 & 12894 & 6003 \\
\hline $\mathbf{2 0 1 8}$ & 6170 & 9118 & 3005 \\
\hline $\mathbf{2 0 1 9}$ & 4615 & 5483 & 2187 \\
\hline $\mathbf{2 0 2 0}$ 03. 31-ig & 1129 & 3316 & $*$ \\
\hline
\end{tabular}

A fentiekből világosan kitünik, hogy az évek elörehaladtával a munkaügyi perek számában jelentős csökkenés mutatkozik. E körben a legszignifikánsabb esetszámcsökkenés a 2018-as évben mutatható ki, amikor a felére estek vissza a munkajog körében indított peres jogviták. E csökkenő tendencia vitán felül áll, de elengedhetetlennek tartjuk felhívni a figyelmet arra a tényre, hogy a csökkenés erőteljesebbé válásának ideje megegyezik az új Pp. hatálybalépésének évével. E körben talán nem túlzás azt kijelenteni, hogy az új eljárásjogi kódex - noha kellő felkészülési idő biztosításával annak tartalma már korábban megismerhetővé vált - egyfajta

${ }^{30}$ https://birosag.hu/statisztikai-evkonyvek (2021. 05. 16.). 
fagyasztó hatást gyakorolhatott (elsősorban a jogi képviselőkre) a perindításokat illetően. ${ }^{31}$

\section{2. Ügyek alakulása II.: peres eljárások tartama}

Álláspontunk szerint az ügyek száma mellett egy igen fontos indikátora lehet a perindítási hajlandóságnak az is, ha szemügyre vesszük és értékeljük azt, hogy az egyes munkaügyi pereket a bíróságok milyen gyorsasággal bírálták el. ${ }^{32}$

2. táblázat. Eljárások időtartama (2015-2020)

\begin{tabular}{|l|c|c|c|c|c|c|c|c|}
\hline \multicolumn{1}{|c|}{ Év } & $\begin{array}{c}\text { Ügyek } \\
\text { száma } \\
\text { összesen }\end{array}$ & $\begin{array}{c}\mathbf{0 - 3} \\
\text { hónap }\end{array}$ & $\begin{array}{c}\mathbf{3 - 6} \\
\text { hónap }\end{array}$ & $\begin{array}{c}\mathbf{6 - 1 2} \\
\text { hónap }\end{array}$ & $\mathbf{1 - 2}$ év & $\mathbf{2 - 3}$ év & $\mathbf{3 - 5}$ év & $\begin{array}{c}\mathbf{5} \text { év } \\
\text { felett }\end{array}$ \\
\hline $\mathbf{2 0 1 5}$ & 14670 & 5470 & 3450 & 2973 & 1791 & 569 & 337 & 80 \\
\hline $\mathbf{2 0 1 6}$ & 14307 & 4873 & 4140 & 3013 & 1545 & 457 & 236 & 43 \\
\hline $\mathbf{2 0 1 7}$ & 12894 & 4731 & 3648 & 2680 & 1288 & 338 & 150 & 59 \\
\hline $\mathbf{2 0 1 8}$ & 9118 & 2411 & 2508 & 2269 & 1361 & 369 & 153 & 47 \\
\hline $\mathbf{2 0 1 9}$ & 5483 & 1679 & 1326 & 1175 & 806 & 322 & 142 & 33 \\
\hline $\mathbf{2 0 2 0 .}$ & 3316 & 1230 & 750 & 602 & 438 & 198 & 112 & 31 \\
\hline $\mathbf{0 3 . 3 1 - i g}$ & $\mathbf{2}$ & & & & & & & \\
\hline
\end{tabular}

A fenti adatokból világosan kivehető, hogy a bíróságok a beérkezett ügyek többségét egy éven belül el tudták bírálni első fokon. A vizsgált évek tekintetében az arányok a következőképpen alakultak:

\footnotetext{
${ }^{31}$ E körben az egyik legjelentősebb változás az új Pp.-ben a keresetlevelek ,jogi sorsának" átalakítása volt (lásd az 1952. évi III. törvény, azaz a régi Pp. 95. § és 130. §, valamint az új Pp. 176. § szakaszait). Szükséges e mellett még utalni a Kúria joggyakorlat-elemző csoportjának megállapításaira is, miszerint a vizsgált 1689 ügyböl azok 2/3 része - egészen pontosan 1146 ügy - végződött a keresetlevél visszautasításával. E kérdésben a vizsgálat nem terjedt ki külön a munkaügyi perekben született keresetlevelekkel kapcsolatos bírósági végzések tartalmára, ugyanakkor a szükséges és keresett arányszám megfeleltethető az új Pp. alapján induló pereken belüli munkaügyi perek mutatószámának. Lásd: A joggyakorlat-elemző csoport összefoglaló véleménye, 2019.EI.II.J.GY.P.2. https://kuria-birosag.hu/sites/default/files/joggyak/a_keresetlevel_ visszautasitasanak_vizsgalata_osszefoglalo_velemeny.pdf (2021. 05. 16.).

${ }^{32}$ A perek gyors és hatékony elbírálásával kapcsolatos általános társadalmi igényt a jogalkotó az új Pp.-ben már az alapelvek között is lefektette: perkoncentráció elve (Pp. 3. §), illetöleg a felek eljárástámogatási kötelezettsége [Pp. 4. § (1)]. KIRÁLY Lilla: A perelőkészítéshez és a bizonyításhoz kapcsolódó új magyar polgári perrendtartás szabályozása a kontinentális és az angolszász jogrendszerek tükrében. Pro Publico Bono Magyar Közigazgatás, 2019/2, 129-135.
} 
3. táblázat. Az egy éven belül és az azon túl befejezett ügyek aránya

(2015-2020)

\begin{tabular}{|l|c|c|c|c|}
\hline \multicolumn{1}{|c|}{ Év } & $\begin{array}{c}\text { 1 éven belüli } \\
\text { befejezett } \\
\text { ügyek száma }\end{array}$ & $\begin{array}{c}\text { 1 éven túl } \\
\text { befejezett } \\
\text { ügyek száma }\end{array}$ & $\begin{array}{c}\text { 1 éven belüli } \\
\text { befejezett } \\
\text { ügyek aránya }\end{array}$ & $\begin{array}{c}\text { 1 éven túl } \\
\text { befejezett } \\
\text { ügyek aránya }\end{array}$ \\
\hline $\mathbf{2 0 1 5}$ & 11893 & 2777 & $81,07 \%$ & $18,93 \%$ \\
\hline $\mathbf{2 0 1 6}$ & 12026 & 2281 & $84,05 \%$ & $15,95 \%$ \\
\hline $\mathbf{2 0 1 7}$ & 11059 & 1835 & $85,76 \%$ & $14,24 \%$ \\
\hline $\mathbf{2 0 1 8}$ & 7188 & 1930 & $78,83 \%$ & $21,17 \%$ \\
\hline $\mathbf{2 0 1 9}$ & 4180 & 1303 & $76,23 \%$ & $23,77 \%$ \\
\hline $\mathbf{2 0 2 0 . 0 3 . 3 1 - i g}$ & 2585 & 731 & $77,95 \%$ & $22,05 \%$ \\
\hline
\end{tabular}

A 2018-as évben megfigyelhető, hogy annak ellenére, hogy a 2017-es évhez képest 3776-tal kevesebb munkaügyi per volt a közigazgatási és munkaügyi bíróságok előtt, a jogviták egy éven túlra húzódó elbírálása arányaiban 6,93\%-kal nőtt. Ez azért is tekinthető ellentmondásnak, mivel az új Pp.-vel kapcsolatos - már érintett - jogalkotási koncepció hangsúlyozottan az eljárások minél gyorsabb és hatékonyabb befejezését célozta. ${ }^{33}$

A tisztességes eljáráshoz való jog korántsem tekinthetö ${ }^{34}$ egyfajta unikális nemzeti igénynek. Az észszerü és hatékony peres gyakorlat iránti igények olyan konkrét nemzetközi dokumentumokban is megfogalmazódtak, mint a CEPEJ ${ }^{35}$ megállapításai és ajánlása. ${ }^{36} \mathrm{~A}$ CEPEJ kifejti, hogy ezen alapjog esetében mindössze egy olyan minimumkövetelményröl beszélhetünk, amely deklarációja önmagában még nem tekinthető adekvátnak a kívánt cél elérése érdekében, azok részkövetelményei ezen okból részletezésre szorulnak. Hangsúlyozza továbbá, hogy a kívánatos eredmény nem az észszerủ időn belül történő befejezéssel érhető el, hanem a legkedvezőbb időkeret felállításával. ${ }^{37}$ Ennek érdekében a javaslat konkrét, gyakorlati eszközök és

${ }^{33} \mathrm{E}$ jogalkotói álláspontot hivatott erősíteni az új $\mathrm{Pp}$. általános indokolásában megjelenő, a perhatékonyság rendszerszintü biztositására irányuló igény, valamint a kódex perkoncentrációval kapcsolatos alapelvi rendelkezéseihez füzött részletes indokolásban kifejtett elvárások. Bővebben: Magyarország Kormányának T/11900. számú törvényjavaslat a polgári perrendtartásról - általános indokolása II. pont 1. alpont és III. pont 1. alpont, valamint a 3. §-hoz füzött részletes indokolás. https://www.parlament.hu/irom40/11900/11900.pdf (2021. 05. 16.).

${ }^{34}$ Ez az igény alapvető jognak tekinthető: az Emberi Jogok Európai Egyezménye 6. cikkének 1. pontjában rögzíti, hogy „[m]indenkinek joga van arra, hogy ügyét a törvény által létrehozott független és pártatlan bíróság tisztességesen nyilvánosan és ésszerü időn belül tárgyalja, és hozzon határozatot polgári jogi jogai és kötelezettségei tárgyában (...)”. Ezen jogosultság alaptörvényi-szintű garanciája: „Mindenkinek joga van ahhoz, hogy ügyeit a hatóságok (...) ésszerü határidőn belül intézzék (...).” Magyarország Alaptörvénye XXIV. cikk (1) bekezdés.

${ }^{35}$ A CEPEJ (European Commission for the Efficiency of Justice), az Európa Tanácsnak az igazságszolgáltatás hatékonyságának növelése és biztosítása érdekében felállított bizottsága.

${ }^{36}$ Az összefoglaló teljes szövege - angol nyelven - elérhető: https://rm.coe.int/16807473ab (2021. 05. 30.).

37 From reasonable time to „optimum” timeframe. https://rm.coe.int/16807473ab (2021. 05. 30.). 
modellek ${ }^{38}$ alkalmazását sürgeti annak érdekében, hogy e társadalmi és jogalkotói igény kézzel fogható eredményekkel mérhetővé váljon.

Az Európai Bizottság minden évben elkészíti az úgynevezett Európai Igazságügyi Táblát ${ }^{39}$ amely az imént vázoltak gyakorlati megvalósulását mutatja be. Ebben vizsgálja a Bizottság (a CEPEJ szempontjai és adatai alapján) az egyes tagállami bíróságok teljesítményét. A magyar igazságszolgáltatási rendszer (és ezen belül a munkaügyi perekben eljáró bírák és bíróságok) a legfrissebb, 2020-as igazságügyi táblában ${ }^{40}$ foglalt jelentések alapján kielégíti e sztenderdeket. Hangsúlyozandó ugyanakkor, hogy az abban foglalt információk pusztán 2018-ig rögzítenek és elemeznek adatokat, így arra nézve, hogy az új eljárásjogi törvényünk adta munkajogi igényérvényesítési keretet a közelmúltban és közeljövőben milyen tényezők befolyásolták és alakítják majd, messzemenő következtetéseket nem lehet levonni.

\section{Következtetések}

Mielött konkrét következtetéseinkre rátérnénk, elengedhetetlennek tartjuk hangsúlyozni, hogy korántsem a jelen tanulmány célja, hogy a helyes jogalkotás - helyes jogalkalmazás (valamelyest utópisztikusnak tekinthetö) objektív kritériumait meghatározzuk, és e követelményrendszer szerinti eljárás helyességét hangsúlyozzuk. Álláspontunk szerint önmagában egy törvénykönyv megalkotása, valamint az ahhoz kapcsolódó, részben megújult eljárási környezet adaptációja egy igen nagy erőfeszítést igénylő, összetett feladat, ugyanakkor az így előáló eredmények értékelésének elmaradása éppen azt az organikus fejlődésre való lehetőséget tagadja meg a jogalkotástól, ${ }^{41}$ amellyel a kialakult helyzetre reagálva, felül tudná bírálni korábbi jogszabályait.

Jelen dolgozat vizsgálati fókuszára ráillesztve a korábbi megállapításokat, tagadhatatlan, hogy a két tárgyalt törvénykönyv hatálybalépése drasztikusnak mondható hatást gyakorolt a munkajogi igényérvényesítés gyakorlatát illetően.

Érzékelhetővé vált, hogy az új anyagi jogi kódex a felek megállapodásának dominanciáját ${ }^{42}$ kívánja a jövőben előtérbe hozni, szélesítve ezzel a szerződő felek szabadságát. A kérdés e körben továbbra is az, hogy képes-e a jelenlegi jogszabályi környezet a munkahelyteremtés céljának szem előtt tartásával akként rugalmasab-

\footnotetext{
${ }^{38}$ A cél elérése érdekében az összefoglaló különböző „időkeretek” kijelölésének felállításában gondolkozik, az alábbi metódus alapján: időkeretek meghatározása - végrehajtás - figyelemmel kísérés és terjesztés - ügykezelési irányelvek felállítása - esetszámra és munkateherre vonatkozó irányelvek felállítása.

${ }^{39}$ EU Justice Scoreboard.

40 https://ec.europa.eu/info/sites/default/files/justice_scoreboard_2020_en.pdf (2021. 05. 30.).

${ }^{41} \mathrm{E}$ kérdésben a hazai jogtudomány is számos irodalommal büszkélkedhet. Például SEBŐK Miklós-MoLNÁR Csaba: A jogalkotás minősége: Elméleti alapok és mérési lehetőségek. In: Sebők Miklós-Gajduschek GyörgyMolnár Csaba (szerk.): A magyar jogalkotás minősége - Elmélet, mérés, eredmények. Gondolat - Társadalomtudományi Kutatóközpont - MTA Kiválósági Kutatóhely, Budapest, 2020, 19-58.; BotTYÁN Béla: Egyes kérdések a minőségi jogalkotás elvéről. Pro Publico Bono - Magyar Közigazgatás, 2015/1, 38-54.

42 Kiss György szavait idézve: „(...) nevelő hatású a szabályozás, mert feldobja a labdát: döntsenek a felek. (...)" - Interjú a X. Magyar Munkajogi Konferencián Berke Gyulával, Kiss Györggyel és Pál Lajossal. https:// jogaszvilag.hu/szakma/megallapodasra-nevel-az-uj-mt/ (2021. 05. 30.).
} 
bá tenni a hazai foglalkoztatást, hogy a munkajog létét indokoló szociális védelmi funkciók devalválódásától a rendszert megóvja. ${ }^{43}$

E kérdést megválaszolni az eltelt idő rövidségére tekintettel lehetetlen, ugyanakkor a már vázolt peradatokból arra lehet gondolni, hogy a munkaügyi jogviták számát érdemben az új eljárásjogi szabályok hatálybalépése apasztotta el ${ }^{44}$ amely arra enged következtetni, hogy az új Pp.-nek köszönhetően nem érvényesítik igényeiket a munkaviszony alanyai peres úton. ${ }^{45}$

Összességében tehát elmondható, hogy a jogszabályváltozások frissességére tekintettel messzire mutató, átfogó következtetések levonása nem lenne bölcs dolog. Ugyanakkor fel kell hívni a figyelmet arra, hogy a bíróság előtti igényérvényesítések számának szignifikáns csökkenése semmiképpen sem értékelhető pozitív fejleménynek, ugyanis nem utal semmilyen bizonyíték arra, hogy a szerződő felek közötti jogviták száma csökkent volna, emiatt pedig arra a következtetésre juthatunk, hogy a visszaélések és jogsértések látenciája növekedett.

${ }^{43}$ Egyetértünk Pál Lajos gondolataival: a modern problémákra nem lehet „elavult” válaszokat adni, ugyanakkor fontos megjegyeznünk, hogy ahhoz, hogy a felvetődő, 21. századi problémákra kielégítő megoldásokkal tudjunk szolgálni, akár egészen a 19. században megfogalmazott alapvetésekig szükséges visszanyúlni, hogy az ott megfogalmazott értékeket, elvi megállapításokat a kor követelményeinek megfelelöen átültethessük, megőrizve ezzel az elvet, és „felújítva” a megjelenést. Lásd PÁL Lajos: Gondolatok a munkajogi szabályozás jövőjéről. Munkaügyi Szemle, 2007/9, 9-11.

${ }^{44}$ Fontosnak tartjuk hangsúlyozni, hogy jelen vizsgálat tárgyát ugyan a 2015 előtti időszak nem képezi - amelyet az új Mt. hatálybalépésének idejével kapcsolatos indokok támasztanak alá -, ugyanakkor megjegyzendő, hogy a munkaügyi perek számában már 2013-tól csökkenő tendencia volt érzékelhető. Bővebben KuN (2016): i. m., 409.

${ }^{45} \mathrm{E}$ körben érdemes figyelmet fordítani arra az ellentmondásra is, hogy a bírósági ügyteher csökkenése nem eredményezte érdemben a peres eljárások időtartamainak számottevő rövidülését - ahogy az a korábbiakban bemutatott táblázatokban szereplő arányszámokból megállapítható. Ez szintén kihatással lehet a perlési kedv csökkenésére. 